\title{
Genetic diversity of 'satellite' bacteria present in cultures of marine diatoms
}

\author{
Hendrik Schäfer ${ }^{\mathrm{a}, 1}$, Ben Abbas ${ }^{\mathrm{b}}$, Harry Witte ${ }^{\mathrm{b}}$, Gerard Muyzer ${ }^{\mathrm{c}, *}$ \\ a Max-Planck Institute for Marine Microbiology, Bremen, Germany \\ b Netherlands Institute for Sea Research, Den Burg, Texel, The Netherlands \\ c Department of Biotechnology, Delft University of Technology, Delft, The Netherlands
}

Received 13 December 2001; received in revised form 9 May 2002; accepted 9 May 2002

First published online 15 July 2002

\begin{abstract}
Uni-algal, non-axenic cultures of six marine diatoms were screened by polymerase chain reaction-denaturing gradient gel electrophoresis for the diversity of the accompanying bacterial communities ('satellite' bacteria) in order to test the hypothesis that algal cells constitute niches for specific bacterial species. The complexity of the satellite assemblages, as judged from the number of detected phylotypes, was low when compared to the complexity of bacterial assemblages in nature. Generally, the six algal cultures were accompanied by distinct satellite assemblages, as the majority of the phylotypes detected in the six cultures were unique, and only some phylotypes were common to more than one culture. Analysis of replicate incubations and repeated passage of cultures in most cases showed only minor variations in satellite assemblage genetic fingerprints, suggesting that the bacterial-algal associations were stable. An experimental approach to find evidence for specific bacterial-algal interactions by challenging algal cultures with heterologous satellite assemblages was unsuccessful as it was not possible to avoid carryover of algae. Satellite populations were identified by sequencing of denaturing gradient gel electrophoresis bands. Most of the populations represented typical marine phylotypes, such as members of the $\alpha$-Proteobacteria (related to the genera Ruegeria, Sulfitobacter, Roseobacter and Erythrobacter), or members of different genera of the Cytophaga-Flavobacterium-Bacteroides (CFB) phylum. Surprisingly, $\beta$-Proteobacteria were also found in two of the cultures. A common point for all cultures was the presence of at least one representative of the $\alpha$-Proteobacteria and of the CFB phylum, both of which have been reported as important representatives of the marine picoplankton. Their ubiquity in the sea and in the phytoplankton cultures analysed points to a specific role of these bacteria in the marine food web. The results indicate that algal diversity might be an important factor in explaining the enormous bacterial diversity in marine assemblages, and vice versa. Specific substances in the photosynthetic extracellular release and in the organic carbon produced by different phytoplankton species may require a variety of bacterial populations for the processing of this algal-derived organic matter. (C) 2002 Federation of European Microbiological Societies. Published by Elsevier Science B.V. All rights reserved.
\end{abstract}

Keywords: Bacterial-algal interaction; Denaturating gradient gel electrophoresis; Diatom; Bacterial diversity; Satellite bacterium; 16S rRNA

\section{Introduction}

So far, most studies on bacterial-algal interactions have focused on the functional roles of phytoplankton and bacteria in the production and utilisation of phytoplanktonderived dissolved organic matter (DOM). Interactions of algae and bacteria have been described in detail elsewhere

\footnotetext{
* Corresponding author. Tel.: +31 (15) 2781193;

Fax: +31 (15) 2782355.

E-mail address: g.muyzer@tnw.tudelft.nl (G. Muyzer).

${ }^{1}$ Present address: Department of Biological Sciences, University of Warwick, Coventry CV4 7AL, UK.
}

[1] and range from symbiotic, via commensal, to parasitic interactions. The carbon demand of heterotrophic bacteria is ultimately met by photosynthetically (algal-) derived carbon sources, except in situations where large inputs of allochthonous (e.g. terrestrial) organic matter are present [2]. Thus DOM, which becomes liberated upon senescence and after lysis of algal cells (e.g. through autolysis or 'sloppy feeding' of microzooplankton), may be an important carbon source for heterotrophic marine bacteria. Stimulation of bacterial growth by extracellular release of organic carbon by photosynthetic algae has led to the formulation of the 'phycosphere' as an important region of interaction of algae and bacteria. In the "phycosphere', motile bacteria in the vicinity of phytoplankton 
cells utilise nutrients and exudates released from phytoplankton which then ultimately do not reach the bulk of the medium for utilisation by other bacteria [3]. Bacteria are important in processing of phytoplankton-derived particulate organic matter (POM). Aggregates ranging in size from marine snow particles to single phytoplankton cells are rapidly colonised by bacteria, whose ectoenzymic activities have important implications, not only for reducing export of organic carbon to the deeper ocean layers, but also for the release of dissolved organic carbon (DOC) to the surrounding medium ([4] and references therein). Development of such DOC hotspots probably allows for higher activity of motile free-living bacterial populations that are attracted chemotactically to the nutrient-rich plume left by sinking POM colonised by bacteria [5]. Furthermore, regeneration of inorganic nutrients, e.g. diatom frustule silica, is increased by colonising bacteria, and differences in ectoenzymic profiles between bacterial populations may provide an important control on biogenic silica regeneration $[6,7]$.

The question of specificity of bacterial-algal interactions in the phycosphere is difficult to address due to the absence of adequate sampling methods. Studies suffer from the inherent complexity of the pelagic food web and the general inability to rule out alternative mechanisms for explaining shifts in bacterial assemblage composition, yet they provide some circumstantial evidence that algal blooms may be able to affect the community composition of pelagic bacteria [8-10]. González et al. [8] reported that estimated abundance of Roseobacter-related bacteria was positively correlated with the concentration of dimethylsulfoniopropionate (DMSP) in samples from a DMSPproducing algal bloom in the North Atlantic, while Riemann and colleagues found that marine $\alpha$-Proteobacteria, as well as members of the Cytophaga-Flavobacterium-Bacteroides (CFB) phylum, responded to the decay of a phytoplankton bloom dominated by Thalassiosira sp. [10].

The aim of this study was to give complementary information on bacterial-algal interactions in systems where the complexity of the microbial community is reduced as compared to the natural situation, namely in diatom cultures. Uni-algal phytoplankton strains as they exist in algal culture collections may harbour a substantial number of commensal bacteria, which have been termed 'satellite' bacteria (e.g. [11]). Given that these phytoplankton cultures are maintained by repeated passage, often over time spans of many years, it is conceivable that particular bacterial populations might be selected to grow in association with their algal hosts. While growth of bacteria in such phytoplankton cultures may, in principle, be photoautotrophic or photoheterotrophic, it should be mainly heterotrophic, as otherwise bacteria would be in direct competition for nutrients and light with the algal cells. Despite the DOM already present in the seawater, labile DOM provided by photosynthetic extracellular release by the algae is the main source of organic carbon for the bacteria. Another carbon source for the bacteria in phytoplankton cultures is POM and DOM after senescence and lysis of the algae. On the one hand, compounds from algal cells may constitute a more or less stringent selection pressure as growth substrates and might invoke development of adapted bacteria [12]. On the other hand, it has been hypothesised that in natural, oligotrophic environments bacteria possess uptake systems for organic carbon that have a high affinity, but a low specificity [13]. Apart from reports on specific bacterial symbionts of marine macroalgae [14], association of microalgae and bacteria in phytoplankton cultures has been demonstrated by isolation of bacterial strains from the cultures. Culturable bacteria isolated from diverse microalgal cultures had a similar phylogenetic affiliation [15]. Culturable bacteria from phytoplankton cultures also encompass toxin-producing bacteria, e.g. tetrodotoxin-producing bacteria from cultures of Alexandrium tamarense [16,17], or Ruegeria algicola, an okadaic acid-producing bacterium from a culture of Prorocentrum lima [18].

The objectives of this study were to analyse the genetic diversity of bacterial assemblages accompanying uni-algal, marine diatom strains and to identify the dominant bacterial groups in these cultures by sequencing 16S rRNA gene fragments. Since satellite assemblages may harbour additional phycosphere-non-specific bacterial populations, such an inventory of bacterial populations may not properly reflect the interaction of algae and phycosphere bacteria but provides bulk characterisation of the satellite assemblage. The composition of the bacterial satellite assemblage was observed over the course of repeated subculture and during different growth phases of the phytoplankton batch culture. Finally, an attempt was made to test the specificity of the association of algae and bacteria experimentally by reciprocally challenging two algal cultures with their respective satellite assemblages.

\section{Materials and methods}

\subsection{Algal cultures and sampling of satellite bacterial assemblages}

The diatom strains used in this study are reported in Table 1. Diatoms were cultured at $15^{\circ} \mathrm{C}$ in seawater base

Table 1

Diatom strains used in this study

\begin{tabular}{lll}
\hline Species & Strain & Source \\
\hline Dytilum brightwellii & CCMP358 & Gulf of Mexico \\
Thalassiosira weissflogii & CCMP1049 & Amityville, NY, USA \\
Asterionella glacialis & Oldenburg & - \\
Chaetoceros socialis & - & Roel Riegman \\
Leptocylindrus danicus & CCMP469 & - \\
Coscinodiscus sp. & - & Jörg Dutz \\
\hline
\end{tabular}


F/2 medium [19], without soil extract in the medium, at a light intensity of $80-170 \mu \mathrm{E} \mathrm{m}^{-2} \mathrm{~s}^{-1}$ ( $8 \mathrm{~h}$ dark/16 h light). Measurement of the absorbance at $435 \mathrm{~nm}$ was used to monitor growth of the algae. At different times samples of the cultures were taken and filtered over $0.2-\mu \mathrm{m}$ pore-size GVWP or GTTP filters (Millipore). Filters were stored at $-80^{\circ} \mathrm{C}$ until further analysis. The type of filter used (GVWP or GTTP) did not affect the results obtained by polymerase chain reaction-denaturing gradient gel electrophoresis (PCR-DGGE) analysis.

\subsection{Reciprocal challenging experiment}

To test the specificity of the bacterial-algal association a reciprocal challenging experiment was carried out as described below. All experimental manipulation was carried

Table 2

Satellite bacterial populations and plastids from diatom cultures identified by partial 16S rRNA gene analysis

\begin{tabular}{|c|c|c|c|c|}
\hline Sequence name ${ }^{\mathrm{a}}$ & Closest relative in database & Accession number & Similarity $(\%)$ & Phytoplankton culture \\
\hline \multicolumn{5}{|l|}{$\alpha$-Proteobacteria } \\
\hline SB-12-Cd & Roseobacter gallaeciensis & Y13244 & 90 & Coscinodiscus sp. \\
\hline SB-13-CS & bacterium P91650 & AF214120 & 93 & Chaetoceros socialis \\
\hline SB-14/19-LD & uncultured marine $\alpha$-Proteobacterium BY-74 & AJ298352 & 99 & Leptocylindrus danicus \\
\hline SB-23-CS & Roseobacter sp. DSS-8 & AF098493 & 98 & Chaetoceros socialis \\
\hline SB-27-CS & Crassostrea virginica symbiont strain CV1 & AF114485 & 98 & Chaetoceros socialis \\
\hline SB-38-TW & Crassostrea virginica symbiont strain CV1 & AF114485 & 98 & Thalassiosira weissflogii \\
\hline SB-40-TW & Sulfitobacter sp. GAI-21 & AF007257 & 98 & Thalassiosira weissflogii \\
\hline SB-43-DB & Erythrobacter sp. MBIC3019 & AB012062 & 97 & Dytilum brightwellii \\
\hline SB-44-DB & uncultured $\alpha$-Proteobacterium HetTri4-79 & AF216503 & 98 & Dytilum brightwellii \\
\hline SB-46-DB & $\alpha$-Proteobacterium SOGA34 & $\mathrm{AJ} 244810$ & 99 & Dytilum brightwellii \\
\hline SB-58-AG & $\alpha$-Proteobacterium Y3F & AF253467 & 92 & Asterionella glacialis \\
\hline SB-59-AG & Roseobacter sp. (Prionitis decipiens symbiont) & AF107210 & 96 & Asterionella glacialis \\
\hline SB-62-AG & Tetracoccus cechii & Y09609 & 92 & Asterionella glacialis \\
\hline SB-8/30-AG & unknown $\alpha$-Proteobacterium JP88 & AY007684 & 97 & Asterionella glacialis \\
\hline SB-82-CS & unidentified $\alpha$-Proteobacterium OM75 & U70683 & 91 & Chaetoceros socialis \\
\hline \multicolumn{5}{|l|}{$\beta$-Proteobacteria } \\
\hline SB-24-CS & uncultured rape rhizosphere bacterium wr0017 & AJ295478 & 99 & Chaetoceros socialis \\
\hline SB-31-AG & uncultured rape rhizosphere bacterium wr0017 & AJ295478 & 100 & Asterionella glacialis \\
\hline \multicolumn{5}{|l|}{$\delta$-Proteobacteria } \\
\hline SB-52-TW & Desulfobacterium indolicum & AJ237607 & 83 & Thalassiosira weissflogii \\
\hline SB-53-TW & Cystobacter ferrugineus (strain $\mathrm{Cb}$ fe27) & AJ233902 & 90 & Thalassiosira weissflogii \\
\hline SB-56-TW & uncultured marine proteobacterium BY-75 & AJ298361 & 92 & Thalassiosira weissflogii \\
\hline \multicolumn{5}{|l|}{ CFB group } \\
\hline SB-10/22-CS & uncultured Cytophagales ESR 4 & AF268288 & 90 & Chaetoceros socialis \\
\hline SB-11/16-Cd & uncultured Cytophagales ESR 4 & AF268288 & 87 & Coscinodiscus sp. \\
\hline SB-15-Cd & uncultured marine eubacterium OTU_C & AF207850 & 97 & Coscinodiscus sp. \\
\hline SB-18-LD & Flavobacteriaceae str. 2 & AB024308 & 98 & Leptocylindrus danicus \\
\hline SB-25-CS & benzene mineralising consortium clone SB-5 & AF029041 & 88 & Chaetoceros socialis \\
\hline SB-29-AG & uncultured CFB group bacterium kpc103f & AF195431 & 99 & Asterionella glacialis \\
\hline SB-35-TW & benzene mineralising consortium clone SB- 5 & AF029041 & 90 & Thalassiosira weissflogii \\
\hline SB-36-TW & uncultured CFB group bacterium kpc103f & AF195431 & 99 & Thalassiosira weissflogii \\
\hline SB-39-TW & uncultured marine eubacterium OTU_B & AF207849 & 90 & Thalassiosira weissflogii \\
\hline SB-42-DB & uncultured bacterium BA2 & AF087043 & 93 & Dytilum brightwellii \\
\hline SB-51-TW & uncultured CFB group bacterium kpc103f & AF195431 & 99 & Thalassiosira weissflogii \\
\hline SB-54-AG & uncultured eubacterium KEppib22 & AF188173 & 95 & Asterionella glacialis \\
\hline SB-6/55-AG & uncultured Microscilla $\mathrm{kpc} 117 \mathrm{f}$ & AF195442 & 99 & Asterionella glacialis \\
\hline SB-63-AG & Cytophaga sp. clone NB1-m & AB013834 & 89 & Asterionella glacialis \\
\hline SB-66-Cd & humic substances enrichment clone D47 & AF231443 & 88 & Coscinodiscus sp. \\
\hline SB-68-Cd & Cytophaga sp. strain BD7-10 & $\mathrm{AB} 015585$ & 89 & Coscinodiscus sp. \\
\hline SB-7/64-AG & uncultured CFB group bacterium NAC60-3 & AF245645 & 87 & Asterionella glacialis \\
\hline SB-83-CS & uncultured CFB group bacterium kpc103f & AF195431 & 96 & Chaetoceros socialis \\
\hline SB-9/21-CS & uncultured marine eubacterium OTU_B & AF207849 & 90 & Chaetoceros socialis \\
\hline \multicolumn{5}{|l|}{ Chloroplasts } \\
\hline SB-1/41-DB & Skeletonema pseudocostatum plastid & $\mathrm{X} 82155$ & 98 & Dytilum brightwellii \\
\hline SB-2/32-TW & Skeletonema pseudocostatum plastid & $\mathrm{X} 82155$ & 99 & Thalassiosira weissflogii \\
\hline SB-3/28-AG & Odontella sinensis plastid & Z67753 & 97 & Asterionella glacialis \\
\hline SB-4/20-CS & Skeletonema pseudocostatum plastid & $\mathrm{X} 82155$ & 97 & Chaetoceros socialis \\
\hline SB-17-LD & uncultured vent bacterium ML-2e & AF208995 & 97 & Leptocylindrus danicus \\
\hline SB-5-Cd & uncultured marine eubacterium HstpL35 & AF159636 & 96 & Coscinodiscus sp. \\
\hline
\end{tabular}

${ }^{\mathrm{a}} \mathrm{AG}$, Asterionella glacialis; CS, Chaetoceros socialis; Cd, Coscinodiscus sp.; DB, Dytillum brightwellii; LD, Leptocylindrus danicus; SB, satellite bacterium; TW, Thalassiosira weissflogii. 
out in a laminar flow hood. All filtrations were performed with sterilised filtration equipment, i.e. vacuum flask, glass funnel and filter holder. Filter discs were stored in cryovials and were transferred to $-80^{\circ} \mathrm{C}$ until use. Cultures of Leptocylindrus danicus and Chaetoceros socialis $(100 \mathrm{ml})$ were grown in triplicate to exponential phase for 13 days, when $75 \mathrm{ml}$ of each culture was aseptically removed. From this $75 \mathrm{ml}, 50 \mathrm{ml}$ was aseptically filtered over GF/C filter discs (47 mm diameter; Whatman, Maidstone, UK). $25 \mathrm{ml}$ of the GF/C filtrate was used as a challenger and was added to $25 \mathrm{ml}$ of the algal culture to be challenged. The volume of the challenged culture was made up to $100 \mathrm{ml}$ using fresh sterile medium. The other half of the $\mathrm{GF} / \mathrm{C}$ filtrate was filtered onto a $0.2-\mu \mathrm{m}$ pore-size filter (GVWP) and was later used for analysis to determine the composition of the challenger assemblage by PCRDGGE. $25 \mathrm{ml}$ of the remaining unmodified algal culture was aseptically filtered with gentle pressure (max. $100 \mathrm{~mm}$ $\mathrm{Hg}$ vacuum) over a $0.2-\mu \mathrm{m}$ filter $(47 \mathrm{~mm}$ GVWP). This was stored at $-80^{\circ} \mathrm{C}$ until analysis of the genetic diversity of the whole cultures on the day of mixing. Two of the triplicate flasks of each algal culture were challenged, the third serving as an unmodified control. For controls, the challenger fraction was added back to the original culture. After 14 days of incubation of all cultures, $25 \mathrm{ml}$ was taken and filtered onto $0.2-\mu \mathrm{m}$ pore-size GVWP filters, after which the cultures were serially transferred into fresh medium and another sampling ( $25 \mathrm{ml}$ onto $0.2 \mu \mathrm{m}$ GVWP filters) was done after a further 21 days of incubation.

\subsection{Extraction of nucleic acids, $P C R-D G G E$, and DNA sequencing}

Extraction of nucleic acids, amplification of 16S rRNA gene fragments, their analysis by DGGE, and sequencing of excised DGGE bands were essentially as described by Schäfer and Muyzer [20]. The primers used for PCR amplification of 16S rRNA gene fragments were 341F-GC (containing a 40-bp GC-rich sequence at the $5^{\prime}$-end) and 907RM, which is an equimolar mixture of the primers 907RC (5'-CCGTCAATTCCTTTGAGTTT-3') and primer 907RA (5'-CCGTCAATTCATTTGAGTTT-3') [20]. PCR products were inspected on $2 \%(\mathrm{w} / \mathrm{v})$ agarose gels and quantified by comparison of band intensities with a molecular mass standard (Precision Molecular Mass Standard; Bio-Rad, Hercules, CA, USA) using the software Multianalyst (Bio-Rad) after scanning gels with a Fluor$\mathrm{S}$ imaging system (Bio-Rad). DGGE analyses were carried out with a DCode system (Bio-Rad) using denaturing gradients of $20-80 \%$ denaturants (see [20] for further details). DGGE bands were sampled for re-amplification and sequencing by punching into individual bands with disposable pipette tips (Mike Ferris, personal communication). The $2.5-\mu 1$ pipette tips used were transferred to disposable $1.5-\mathrm{ml}$ microcentrifuge tubes that contained $10 \mu \mathrm{l}$ of PCR buffer so that the tip would be immersed in the buffer. After overnight incubation at $4^{\circ} \mathrm{C}, 1-5 \mu 1$ of the buffer was taken as template for re-amplification of DGGE bands. Re-amplified PCR products were inspected alongside the original sample on DGGE to verify identity and purity of the bands. PCR products were purified using the QIAquick PCR purification kit (Qiagen). Sequencing was carried out using the ABI Prism ${ }^{\circledR}$ BigDye Terminator ${ }^{\circledR i}$ Cycle Sequencing Kit (PE Biosystems, Foster City, CA, USA) as described by Schäfer and Muyzer [20] using the PCR primers (without GC-clamp).

\subsection{Comparative sequence analysis}

The new partial sequences were analysed using BLAST

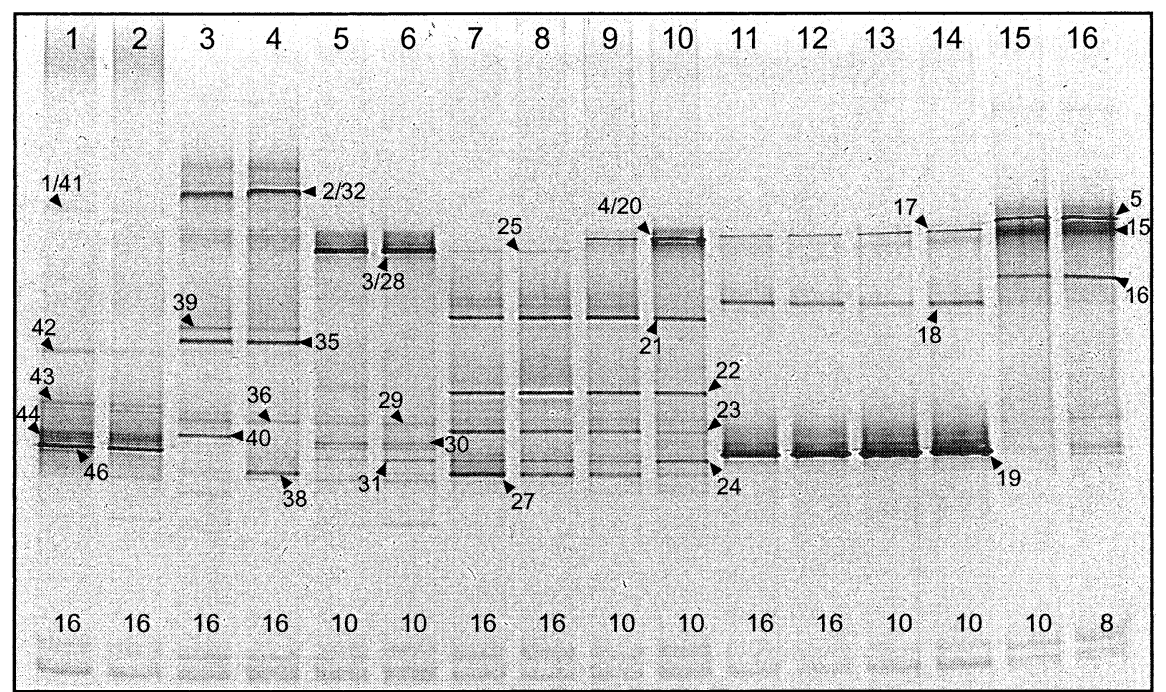

Fig. 1. DGGE analysis of PCR-amplified 16S rRNA gene fragments obtained from six uni-algal, non-axenic diatom cultures. Lanes: 1 and 2, Dytilum brightwellii; 3 and 4, Thalassiosira weissflogii; 5 and 6, Asterionella glacialis; 7-10, Chaetoceros socialis; 11 and 12, Leptocylindrus danicus (16-day-old culture); 13 and 14, Leptocylindrus danicus (10-day-old culture); 15 and 16, Coscinodiscus sp. The age of the culture (in days) is indicated at the bottom of the lanes. The double bands at the bottom of the gel are single-stranded DNA. 

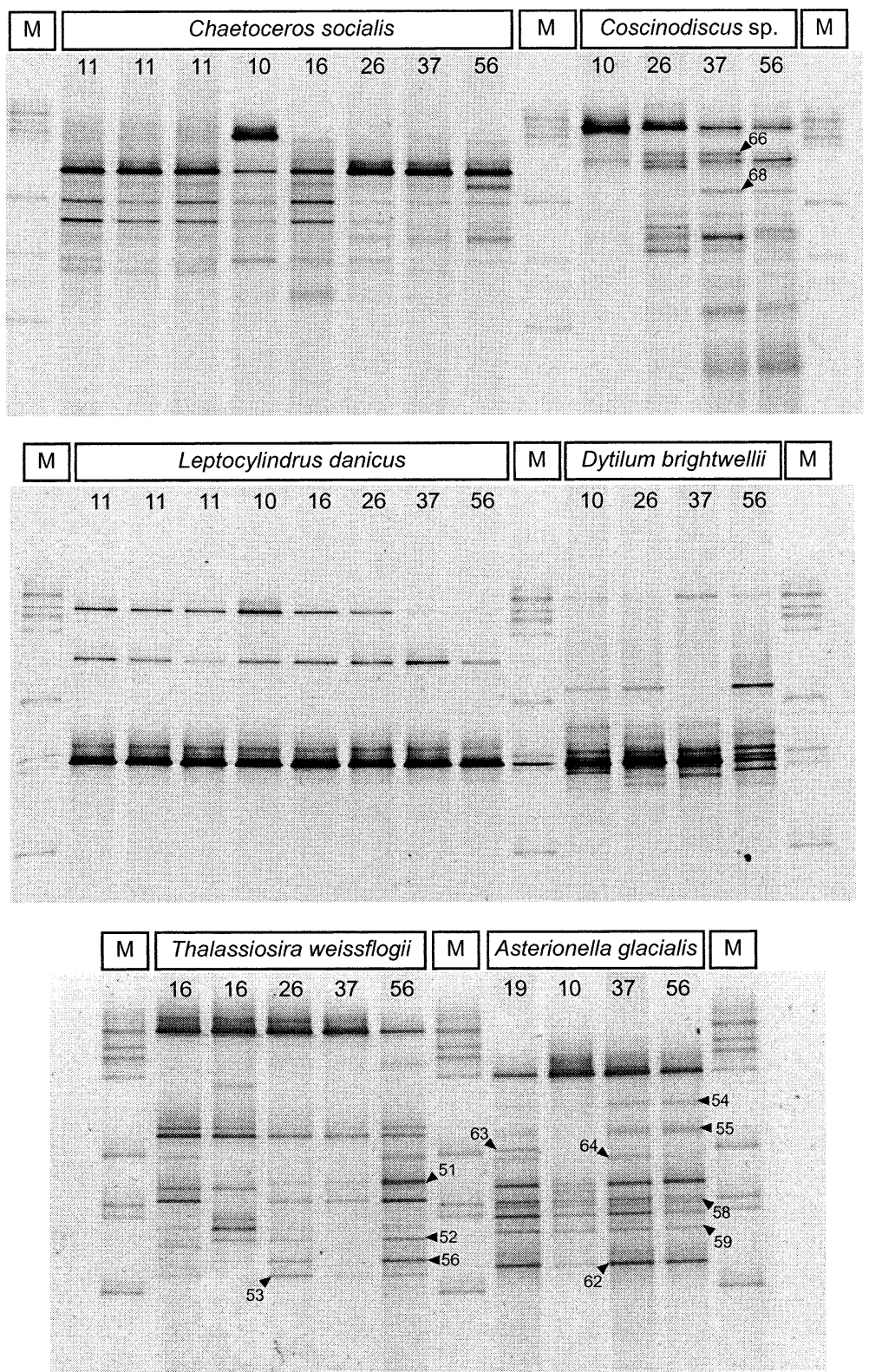

Fig. 2. DGGE analysis of diatom cultures in different growth phases. The name of the culture is indicated above the respective lane; M indicates a marker lane. The age of the cultures on the day of sampling (in days) is indicated at the top of the lanes.

[21] at the NCBI database (http://ncbi.nlm.nih.gov/ BLAST) and aligned together with the highest scoring BLAST hits, to an alignment of homologous bacterial 16S rRNA sequences [22] using the aligning tool included in the ARB software package [23]. Neighbour-joining trees were generated using NEIGHBOR [24] with the Kimura two-parameter model taking into account all overlapping unambiguous nucleotides within a given set of sequences. Sequences obtained in this study have been deposited in the sequence databases at the European Molecular Biology Laboratory (EMBL) under accession numbers AJ319823-AJ319866. The names of sequences consist of the prefix SB (for satellite bacteria), a DGGE band num- ber, and an abbreviation of the diatom culture in which the satellite bacterium was detected (see Table 2).

\section{Results}

\subsection{Genetic diversity of satellite bacterial populations}

DGGE analysis showed that the satellite bacterial assemblages of each culture were unique (Fig. 1). No significant overlap of band positions was observed between cultures. There were also marked differences in richness over all cultures, the least in $L$. danicus (four to five bands) and 
most in Thalassiosira and Chaetoceros with 20 and 16 bands maximum, respectively.

\subsection{Reproducibility of the composition of satellite bacterial assemblages}

Analysis of samples from duplicates (Fig. 1) showed that the genetic diversity of the algal-bacterial cultures was generally reproducible. Some variation was recorded in the case of the cultures of Thalassiosira weissflogii but, except for two bands (bands SB-40-TW, SB-38-TW), the differences were mainly due to differences in band intensities. Fig. 1 further shows that variation was also recorded when algal-bacterial cultures of Chaetoceros socialis were sampled at different times. While the band corresponding to the plastid of the algae (band 4/20) was visible in samples taken after 10 days of incubation, it could not be detected after 16 days of incubation. This finding might indicate that the algae were not detectable either due to altered extractability of the plastid DNA or, more probably, due to growth of bacteria.

\subsection{Genetic diversity of satellite bacterial assemblages in different phases of growth and senescence}

In addition to $C$. socialis and $L$. danicus taken after 10 or 16 days, a more extensive survey of the genetic diversity of all six cultures was done spanning a period of almost 2 months with samples taken after 10, 16, 26 (L. danicus and C. socialis only), 37 and 56 days (Fig. 2). In most cases DGGE profiles were very similar, even between exponential-phase (10 days) and senescent-phase cultures. Although DGGE data do not strictly allow quantitative estimates of community composition, marked changes in the intensity of bands in different samples of all cultures strongly suggest that the relative abundance of different satellite populations changed over the course of batch incubation.

The culture of Dytilum brightwellii seemed very stable in composition, even over a time span of 56 days. A minor variation concerned band 42 (see Fig. 1), which was absent from the genetic fingerprint obtained after 37 days of incubation. The only change in the culture of $L$. danicus consisted in the disappearance of the plastid band (band 17, Fig. 1), probably due to senescence of the algae. In all other cultures variations in the banding patterns of the bacterial populations occurred.

The variability in the cultures of $C$. socialis mostly concerned the detectability of the chloroplast $16 \mathrm{~S}$ rRNA gene (see above). The Asterionella glacialis chloroplast gene (band 3/28, see Fig. 1) was detectable in each sample, but it was strongest (in comparison with bands of bacterial populations) in the day 10 sample, indicating that bacterial populations were less well represented in the fingerprints, probably as a consequence of relatively lower total bacterial biomass.

In Thalassiosira cultures most variation was recorded between the samples obtained from duplicate cultures after 16 days. All other samples corresponded very well with the pattern of one of the duplicate 16-day-old cultures. The culture of Coscinodiscus was the only one in which a succession during prolonged incubation was recorded (Fig. 2, top panel). Generally, the richness of the satellite assemblage of Coscinodiscus increased as judged from the increase in the number of DGGE bands. Two additional populations detected in 37-day-old cultures were identified as members of the CFB. Unfortunately, attempts to sequence further newly appearing DGGE bands were not successful. It remains unpredictable whether freshly inoculated Coscinodiscus cultures would show similar successions, and the reproducibility after repeated passage is not certain.

\subsection{Identity of bacterial satellite populations}

The identification of satellite bacterial populations obtained by sequencing of DGGE bands is reported in Table 2 and Fig. 3. The overall diversity was high. In addition to plastids of the diatoms, members of the $\alpha$-, $\beta$-, and $\delta$-subdivisions of the Proteobacteria and members of the CFB group were identified by sequencing of DGGE bands.

There was a unifying theme in assemblage composition across all cultures, consisting in the presence of at least one type each of $\alpha$-Proteobacteria and CFB group members in each culture. Among the phylotypes detected were typical marine representatives, e.g. the phylotypes from the Rhodobacter group of the $\alpha$-Proteobacteria (related to the genera Roseobacter, Sulfitobacter and Ruegeria), as well as other marine $\alpha$-Proteobacteria (related to the

Fig. 3. Phylogenetic trees showing the relationships of sequences retrieved from DGGE bands from algal and bacterial strains to reference sequences obtained from GenBank (accession numbers of the sequences are given in parentheses). Names of sequences determined in this study are in bold and consist of the prefix SB-, a number referring to individual DGGE bands indicated in Figs. 1 and 2, and an abbreviation of the algal host species as indicated in Table 2. Some sequences have two numbers which indicates that the same band was retrieved and sequenced from two separate PCR products and DGGE gels. (The DGGE gel of bands 1-14 is not shown.) All duplicates had identical sequences. For example, sequence 'SB-10/22CS' was analysed from DGGE bands 10 and 22, and was retrieved from the banding pattern of a $C$. socialis culture. A: $\alpha$-Proteobacteria. B: $\beta$-Proteobacteria. C: $\delta$-Proteobacteria. D: CFB phylum. E: Algal plastids. Sequences marked with three asterisks had little overlap with the rest of the alignment and were therefore inserted into the tree using the special ARB parsimony tool. 
genus Erythrobacter), a marine lineage formed by as yet uncultured members of the $\delta$-Proteobacteria, as well as some of the CFB detected. Some sequences were atypical or hitherto not detected in marine samples. These encom- passed the sequence distantly related to the Myxobacteria (SB-53-TW) and the $\beta$-proteobacterial phylotype very similar to a $16 \mathrm{~S}$ rRNA gene sequence obtained from the rhizosphere of rape (GenBank entry AJ295478). An interest-
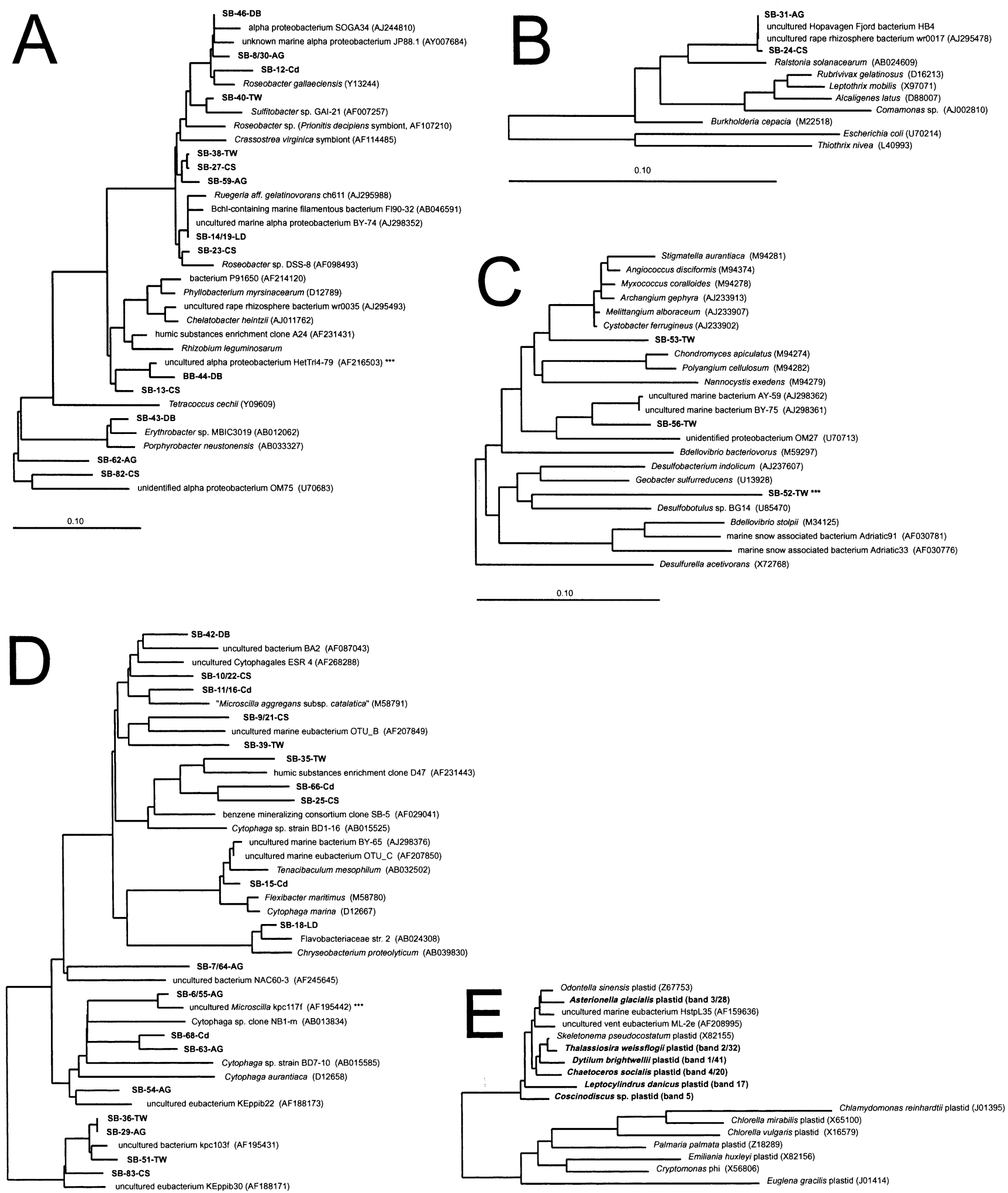


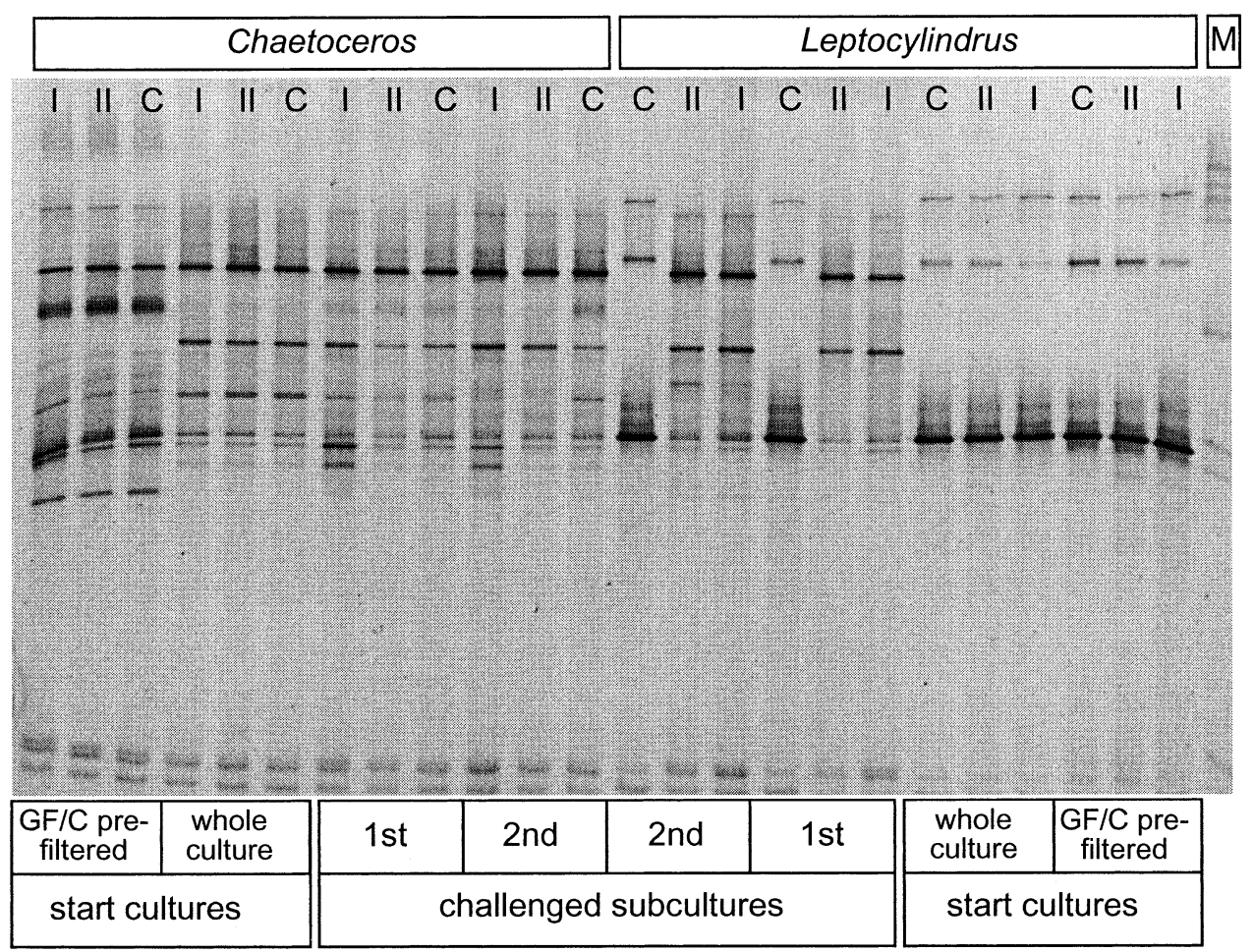

Fig. 4. DGGE analysis of the reciprocal challenging experiment to test the specificity of the association of algal hosts and satellite bacterial assemblages. The purpose of each sample is summarised at the bottom of the figure. The bands at the bottom of the gel are single-stranded DNA. I, II, and C indicate that the sample was from challenged culture $\# 1$, culture $\# 2$, or the unmodified control culture of a series. $\mathrm{M}$ indicates a marker lane.

ing observation was that $\delta$-Proteobacteria were only detected in the cultures of $T$. weissflogii.

\subsection{Stability of algal-bacterial co-culture: reciprocal challenging of $L$. danicus and $C$. socialis cultures}

The results of the challenging experiment are shown in Fig. 4. DGGE analysis showed that in the challenged cultures of $L$. danicus the band corresponding to the plastid of $C$. socialis appeared upon subculture together with the complete set of bands from the Chaetoceros culture. This indicates that the filtration over a GF/C filter did not retain all cells of Chaetoceros and that the challenged cultures of Leptocylindrus were quickly taken over and dominated by Chaetoceros and its satellite community. The control culture of Leptocylindrus remained stable, also after another subculture. In contrast, the Leptocylindrus satellite community was not able to modify the composition of the Chaetoceros culture.

\section{Discussion}

\subsection{Uniqueness and reproducibility of satellite assemblages}

All six cultures had distinct satellite assemblages whose compositions seemed to be stable. For Coscinodiscus only this could not be substantiated due to the limited number of samples analysed.

\subsection{Satellite assemblages in different growth phases}

Limited changes in banding patterns from samples of different ages indicated that satellite populations changed little between different growth phases, and can thus be considered stable assemblages. Minor variation in relative intensities and appearance of single extra DGGE bands in some samples, as observed in cultures of Asterionella and Thalassiosira, suggested that changes in evenness occurred without rendering the composition of the satellite assemblages unstable. The exceptions to this were cultures of Coscinodiscus, where marked changes were observed between growth phases. While additional infection of the cultures during the incubation period cannot be excluded, it seems unlikely as this should potentially have occurred for all other cultures as well.

\subsection{Coincidental selection or specific co-occurrence of algae and bacterial satellites}

For a number of reasons it is suggested that the observed patterns in the composition of the satellite assemblages are not coincidental, but to some extent the result of a selection process that enriches some well adapted bacterial populations. These may not be obligate but rather facultative satellites of their algal hosts. While Bell [2] has suggested that native marine bacteria feed on a small set of low molecular mass compounds that may have been excreted by algae [2], he also pointed out that long-term 
selection should favour populations that are well adapted to the spectrum of organic carbon offered by the algae.

The bacterial seeding stock at the time of isolation of the algae (i.e. the species composition of the inoculum) might also be expected to influence the outcome of the satellite assemblage to some degree, yet it should not preclude selection of suitable satellite bacteria, because culture-dependent approaches in marine microbial ecology suggest that species are present that are not detectable by molecular methods [25,26]. Even if gross differences existed between inocula at the time of isolation of the algae, it may be expected that most samples share a set of taxa that are viable and present in low abundance. Numbers of genomes estimated to be present in environmental samples by DNA reassociation kinetics have shown the presence of thousands of genomes in soil samples. Although bacterioplankton samples show much lower complexity - in the order of around 165 genomes in freshwater [27] - there should be a sufficient diversity of bacterial populations to allow for selection of well adapted types, and make predominance of any kind of population that is selected eventually non-random. Observation of different and unique genetic fingerprints from satellite assemblages in these cultures therefore strongly suggests that there may be true co-occurrences between algae and bacteria in these diatom-bacterial cultures, formed by pairs of algae and bacteria that can co-exist efficiently.

\subsection{Phylotypes identified in diatom cultures}

To date there are no descriptions of satellite bacterial assemblages in the literature. Thus the discussion of phylotypes found in diatom cultures refers to marine bacterial diversity in general. Additionally, there exist a number of GenBank sequence database entries that suggest that microalgal cultures have also been studied by others. In fact many of these sequences turned out to be close relatives of sequences determined in this study. Although algal cultures from strain collections represent artificial environments for both algae and bacteria, they harboured a range of phylotypes representative of several typical lineages of marine picoplankton.

While $\beta$-Proteobacteria are often very abundant in freshwater habitats, in most cases they are present in low abundance or are not detectable in marine samples and therefore have not been considered typical members of marine bacterioplankton [28,29]. The exception to this are populations of ammonia-oxidising bacteria from the $\beta$-subdivision of the Proteobacteria which have been detected in marine sediments by PCR amplification using group-specific primers [30]. Although detection of other $\beta$-Proteobacteria in coastal marine environments by molecular cloning techniques [9,26,31-33], fluorescent in situ hybridisation [28,34], and whole genome probing [35] has been reported, it has never been clear whether these constituted indigenous marine populations or rather were of terrestrial or freshwater origin. Therefore, an inability to grow at ionic strength of seawater has been suggested as a physiological explanation for the absence of $\beta$-Proteobacteria in marine samples $[29,36]$, but there have also been some examples of isolation of $\beta$-Proteobacteria from marine samples $[35,37]$. The finding of $\beta$-proteobacterial phylotypes in these marine diatom cultures is interesting, as it further corroborates that at least some $\beta$-Proteobacteria are able to grow at marine salt concentration. However, the $\beta$-Proteobacteria found in this study were not closely related to any other $\beta$-proteobacterial phylotypes retrieved from marine samples, but formed a distinct cluster with a cloned 16S rRNA gene obtained from rhizosphere samples of rape. The only common factor in these very contrasting environments seems to be the association or proximity to 'plant tissue' probably forming microzones that receive plant-derived organic molecules. Finding the same phylotype in DGGE patterns of samples from the Norwegian landlocked bay Hopavågen suggests that it does not represent an artefact of the culture conditions, but that these bacteria may at times be predominant members of marine microbial communities [38]. In contrast to finding unusual $\beta$-Proteobacteria, no band was affiliated with $\gamma$-Proteobacteria, which are rather typical members of marine bacterioplankton. This might suggest that there is no important role for $\gamma$-Proteobacteria in algal (diatom)-bacterial interactions. Yet, $\gamma$-Proteobacteria have been found, for instance as tetrodotoxin producers, in cultures of toxic dinoflagellates [17], and might not be important in associations with diatoms, but instead link to other types of algae, e.g. dinoflagellates.

There was a predominance of typical marine $\alpha$-Proteobacteria and members of the CFB phylum. Considering the findings of Cottrell and Kirchman [39], the hypothesised main roles of $\mathrm{CFB}$ and $\alpha$-Proteobacteria are enzymatic breakdown of macromolecular DOM and utilisation of small molecular mass carbon units, respectively. Although this does not preclude involvement of $\alpha$-Proteobacteria in degradation of complex organic matter by extracellular enzymatic activities, as suggested by Riemann et al. [10], it has also been shown by Cottrell and Kirchman [39] that no single phylogenetic group (i.e. CFB or $\alpha$-Proteobacteria) dominated the consumption of all high or low molecular mass carbon.

\subsection{Methodological considerations}

This study addressed the diversity of the 'bulk' satellite assemblage of different diatom species. The issue of specific associations could unfortunately not be answered using the experimental set-up of the reciprocal challenging experiment. Future studies might apply different strategies to pursue this question further. Comparison of satellite assemblages of several strains of one species, or re-infection with different natural bacterial assemblages as inocula of algal cultures that are made axenic in a first step with 
subsequent monitoring of the enrichment process by molecular methods may yield valuable information.

Division of algal-bacterial cultures by membranes that bacteria can, but diatoms cannot pass, and monitoring of the development of the bacterial assemblages on either side in the culture vessel might even help to identify 'phycosphere'-specific bacteria. Long and Azam [40] used a PCR-DGGE strategy for testing of microscale patchiness of bacterioplankton assemblage richness in seawater. This strategy might be adapted to test for differences between microlitres of culture either containing or not containing diatom cells.

\subsection{Conclusions}

Due to methodological constraints, direct proof of specific co-occurrence of bacteria and algae could not be gathered, yet the results presented here strongly suggest that laboratory diatom cultures harbour distinct bacterial satellite assemblages. These satellite assemblages do not necessarily represent bacteria from the phycosphere as the phycosphere was neither tested nor sampled for in any way. Yet, a common pattern of community composition was found constituting an elementary microbial community that is composed of a photosynthetic alga and members of the CFB and $\alpha$-Proteobacteria. The common theme of predominance of $\alpha$-Proteobacteria and members of the CFB group in all cultures may reflect specialisation in DOM and POM utilisation, respectively, whereby POM breakdown might be carried out especially (but not necessarily exclusively) by the CFB. $\alpha$-Proteobacteria may also be involved in ectohydrolytic breakdown of POM, yet have mainly been implicated in uptake of small organic molecules and hence might co-feed on the organic matter made available by extracellular enzymic activity of CFB.

\section{Acknowledgements}

The Coscinodiscus strain used in this study was kindly provided by Jörg Dutz. This work was supported by the European Community (MAS3-CT96-0047) and by the Max Planck Society, Munich. The comments of two anonymous reviewers are gratefully acknowledged.

\section{References}

[1] Cole, J.J. (1982) Interactions between bacteria and algae in aquatic ecosystems. Annu. Rev. Ecol. Syst. 13, 291-314.

[2] Bell, W.H. (1984) Bacterial adaptation to low-nutrient conditions as studied with algal extracellular products. Microbiol. Ecol. 10, 217 230.

[3] Bell, W.H. and Mitchell, R. (1972) Chemotactic and growth responses of marine bacteria to algal extracellular products. Biol. Bull. 143, 265-277.

[4] Azam, F. and Long, R.A. (2001) Sea snow microcosms. Nature 414, 495-498.
[5] Kiørboe, T. and Jackson, G.A. (2001) Marine snow, organic solute plumes, and optimal chemosensory behavior of bacteria. Limnol. Oceanogr. 46, 1309-1318.

[6] Bidle, K.D. and Azam, F. (1999) Accelerated dissolution of diatom silica by marine bacterial assemblages. Nature 397, 508-512.

[7] Bidle, K.D. and Azam, F. (2001) Bacterial control of silicon regenerationfrom diatom detritus: significance of bacterial ectohydrolase and species identity. Limnol. Oceanogr. 46, 1606-1623.

[8] González, J.M., Simó, R., Massana, R., Covert, J.S., Casamayor, E.O., Pedrós-Alió, C. and Moran, M.A. (2000) Bacterial community structure associated with a dimethylsulfoniopropionate-producing North Atlantic algal bloom. Appl. Environ. Microbiol. 66, 42374246.

[9] Kerkhof, L.J., Voytek, M.A., Sherrell, R.M., Millie, D. and Schofield, O. (1999) Variability in bacterial community structure during upwelling in the coastal ocean. Hydrobiologia 401, 139-148.

[10] Riemann, L., Steward, G.F. and Azam, F. (2000) Dynamics of bacterial community composition and activity during a mesocosm diatom bloom. Appl. Environ. Microbiol. 66, 578-587.

[11] Borisova, E.V. (1986) Some features of the cultivated community of Dunaliella-spp. and bacteria. [Ukranian]. Ukrayin. Bot. Zh. 43, 6063.

[12] Janse, I., Zwart, G., van der Maarel, M. and Gottschal, J.C. (2000) Composition of the bacterial community degrading Phaeocystis mucopolysaccharides in enrichment cultures. Aquat. Microb. Ecol. 22, 119-133.

[13] Poindexter, J.S. (1981) Oligotrophy: fast and famine existence. Adv. Microb. Ecol. 5, 63-89.

[14] Ashen, J.B. and Goff, L.J. (2000) Molecular and ecological evidence for species specificity and coevolution in a group of marine algalbacterial symbioses. Appl. Environ. Microbiol. 66, 3024-3030.

[15] Borisova, E.V. (1996) Species composition of bacteria accompanying microalgae in culture [Ukranian]. Algologia 6, 303-313.

[16] Simidu, U., Noguchi, T., Hwang, D.F., Shida, Y. and Hashimoto, K. (1987) Marine bacteria which produce tetrodotoxin. Appl. Environ. Microbiol. 53, 1714-1715.

[17] Simidu, U., Kita Tsukamoto, K., Yasumoto, T. and Yotsu, M. (1990) Taxonomy of four marine bacterial strains that produce Tetrodotoxin. Int. J. Syst. Bacteriol. 40, 331-336.

[18] Lafay, B., Ruimy, R., Rausch De Traubenberg, C., Breittmayer, V., Gauthier, M.J. and Christen, R. (1995) Roseobacter algicola sp. nov., a new marine bacterium isolated from the phycosphere of the toxinproducing dinoflagellate Prorocentrum lima. Int. J. Syst. Bacteriol. 45, 290-296.

[19] Riegman, R., Stolte, W., Noordeloos, N. and Slezak, D. (2000) Nutrient uptake and alkaline phosphatase (EC 3:3) activity of Emiliania huxleyi (Prymnesiophyceae) during growth under $\mathrm{N}$ and $\mathrm{P}$ limitation in continuous cultures. J. Phycol. 36 (1), 87-96.

[20] Schäfer, H. and Muyzer, G. (2001) Denaturing gradient gel electrophoresis in marine microbial ecology. Methods Microbiol. 30, 425468.

[21] Altschul, S.F., Gish, W., Miller, W., Myers, E.W. and Lipman, D.J. (1990) Basic Local Alignment Search Tool. J. Mol. Biol. 215, 403410.

[22] Maidak, B.L., Olsen, G.J., Larsen, N., Overbeek, R., McCaughey, M.J. and Woese, C.R. (1997) The RDP (Ribosomal Database Project). Nucleic Acids Res. 25, 109-110.

[23] Strunk, O. and Ludwig, W. (1998) ARB: A Software Environment for Sequence Data. Department of Microbiology, Technical University, Munich.

[24] Felsenstein, J. (1993) Phylip (Phylogeny Inference Package) version 3.5c. Distributed by the author. Department of Genetics, University of Washington, Seattle, WA.

[25] Bernard, L., Schäfer, H., Joux, F., Courties, C., Muyzer, G. and Lebaron, P. (2000) Genetic diversity of total, active and culturable marine bacteria in coastal seawater. Aquat. Microb. Ecol. 23, 111. 
[26] Suzuki, M., Rappé, M.S., Haimberger, Z.W., Winfield, H., Adair, N., Strobel, J. and Giovannoni, S.J. (1997) Bacterial diversity among small-subunit rRNA gene clones and cellular isolates from the same seawater sample. Appl. Environ. Microbiol. 63, 983-989.

[27] Ritz, K., Griffiths, B.S., Torsvik, V.L. and Hendriksen, N.B. (1997) Analysis of soil and bacterioplankton community DNA by melting profiles and reassociation kinetics. FEMS Microbiol. Lett. 149, 151156.

[28] Glöckner, F.O., Fuchs, B.M. and Amann, R. (1999) Bacterioplankton compositions of lakes and oceans: A first comparison based on fluorescence in situ hybridization. Appl. Environ. Microbiol. 65, 3721-3726.

[29] Nold, S.C. and Zwart, G. (1998) Patterns and governing forces in aquatic microbial communities. Aquat. Ecol. 32, 17-35.

[30] McCaig, A.E., Phillips, C.J., Stephen, J.R., Kowalchuk, G.A., Harvey, S.M., Herbert, R.A., Embley, T.M. and Prosser, J.I. (1999) Nitrogen cycling and community structure of proteobacterial betasubgroup ammonia-oxidizing bacteria within polluted marine fish farm sediments. Appl. Environ. Microbiol. 65, 213-220.

[31] Kelly, K.M. and Chistoserdov, A.Y. (2001) Phylogenetic analysis of the succession of bacterial communities in the Great South Bay (Long Island). FEMS Microbiol. Ecol. 35, 85-95.

[32] Rappé, M.S., Kemp, P.F. and Giovannoni, S.J. (1997) Phylogenetic diversity of marine coastal picoplankton 16S rRNA genes cloned from the continental shelf off Cape Hatteras, North Carolina. Limnol. Oceanogr. 42, 811-826.
[33] Rappé, M.S., Vergin, K. and Giovannoni, S.J. (2000) Phylogenetic comparisons of a coastal bacterioplankton community with its counterparts in open ocean and freshwater systems. FEMS Microbiol. Ecol. 33, 219-232.

[34] Cottrell, M.T. and Kirchman, D.L. (2000) Community composition of marine bacterioplankton determined by $16 \mathrm{~S}$ rRNA gene clone libraries and fluorescence in situ hybridization. Appl. Environ. Microbiol. 66, 5116-5122.

[35] Pinhassi, J. and Hagström, Å. (2000) Seasonal succession in marine bacterioplankton. Aquat. Microb. Ecol. 21.

[36] Glöckner, F.O., Amann, R., Alfreider, A., Pernthaler, J., Psenner, R., Trebesius, K. and Schleifer, K.H. (1996) An in situ hybridization protocol for detection and identification of planktonic bacteria. Syst. Appl. Microbiol. 19, 403-406.

[37] Hagström, Å., Pinhassi, J. and Zweifel, U.L. (2000) Biogeographical diversity among marine bacterioplankton. Aquat. Microb. Ecol. 21, 231-244.

[38] Schäfer, H., Vadstein, O., Olsen, Y. and Muyzer, G. (unpublished results).

[39] Cottrell, M.T. and Kirchman, D.L. (2000) Natural assemblages of marine proteobacteria and members of the Cytophaga-Flavobacter cluster consuming low- and high-molecular-weight dissolved organic matter. Appl. Environ. Microbiol. 66, 1692-1697.

[40] Long, R.A. and Azam, F. (2001) Microscale patchiness of bacterioplankton assemblage richness in seawater. Aquat. Microb. Ecol. 26, 103-113. 